\title{
Moral is political \\ Notions of ideal citizenship in Lie Kim Hok's Hikajat Khonghoetjoe
}

\author{
EvI SuTRISNo
}

\begin{abstract}
This paper argues that the Hikajat Khonghoetjoe (The life story of Confucius), written by Lie Kim Hok in 1897, is a medium to propose modern ideas of flexible subjectivity, cosmopolitanism, active citizenship and the concepts of good governance to the Chinese Peranakans who experienced political and racial discrimination under Dutch colonization. Using the figure of Confucius, Lie aimed to cultivate virtuous subjects who apply their faith and morality in political sphere. He intended to raise political awareness and rights among the Chinese as colonial subjects and to valorize their bargaining power with the Dutch colonial government. By introducing Confucianism, Lie proposed that the Chinese reconnect themselves with China as an alternative patronage which could subvert White supremacy. Instead of using sources in Chinese, Lie translated the biography of Confucius from the European texts. In crafting his story, Lie applied conglomerate authorship, a technique commonly practised by Malay authors. It allowed him to select, combine and appropriate the source texts. To justify that Confucius' virtue and his teaching were superb and are applicable to contemporary life, Lie borrowed and emphasized European writers' high appraisal of Confucianism, instead of using his own arguments and opinions. I call this writing technique "indirect agency".

KEYWORDS

Confucianism; the biography of Confucius; Chinese-Indonesians; Lie Kim Hok; active citizenship; cosmopolitanism.
\end{abstract}

EVI SUTRISNO is a PhD student in Anthropology, the University of Washington, Seattle. Her research investigates the foundation and development of the Confucian religion (agama Khonghucu) in Indonesia from the 1890s to 2010. Her dissertation discusses the agencies of the Chinese-Indonesians in developing their unique religious rituals and concepts and their negotiations with the postcolonial Indonesian state. Evi Sutrisno can be contacted at: evis@ uw.edu. 


\section{INTRODUCTION ${ }^{1}$}

Despite the claim that Confucianism is an ancient teaching dating back to Confucius' own era (551-479 BC), Confucianism in Indonesia was introduced into the Netherlands East Indies by the Chinese Peranakan² no earlier than the late nineteenth century. In this period there was an unprecedented and prolific introduction of Confucianism as the religion of the Chinese people. Several efforts had been made, such as the suggestion to use a new calendar based on the birth date of Confucius in the early 1880s by the Chinese Peranakans of Surabaya. This was followed by the changing of the veneration of the deity of the Wenchang $\mathrm{Ci}$, a temple built in 1884 and originally dedicated to the God of Literature, to Wen Miao (Boen Bio - in Hokkien), which is now principally given over to the veneration of Confucius, in Surabaya in 1899 (Salmon 2005: 130-133). The figure of Confucius himself was introduced into Malay for the first time by the publication of Hikajat Khonghoetjoe (The life story of Confucius), written by Lie Kim Hok in 1897. The first Confucian canon to be published in Malay in 1900 by Njio Tjoen Ean, a Chinese captain of Ambon, was Soe Sie Pek Boen. As the majority of the Chinese Peranakan had lost their Chinese language skills, instead of translating their works from Chinese sources, both Lie and Njio borrowed their ideas from European texts.

The prolific efforts to introduce Confucianism as a religious teaching on the cusp of the twentieth century can be seen as a groundbreaking strategy which eventually established Confucianism in Indonesia in its current unique position as an institutionalized religion, instead of the philosophy or morality practised in other countries, such as China, Japan, Singapore, and Korea. This paper analyses the Hikajat Khonghoetjoe (hereafter HK), understood to be a text central to the introduction of Confucianism in the early of the twentieth century, in order to illuminate the entanglement between religiosity and various political, social, and economic factors faced by the Chinese in the Netherlands East Indies. Instead of being based on earlier Chinese texts, the $H K$ is a translation and appropriation of two western texts. This paper analyses the agency of a Malay author and the process of translation commonly practised in his tradition. In a period of growing interest in Confucianism and Chinese nationalism, the $H K$ was reprinted as many as four times, which presumably an indication of a wide readership (Salmon 1981: 231). ${ }^{3}$

1 I dedicate this article to Laurie J. Sears and Francisco Benitez who drew my interest to study the Sino-Malay literature. I owe a huge debts to Laurie Sears for providing insightful feedback, Henk Maier for insisting that Lie must have basing himself from the Dutch sources, Maya Liem for encouraging me to write this article, Andri Harianja for proof-reading my Chinese and Dutch translations, Putri Santoso for my French translation, and Hollis Miller for my English draft. However, I should be responsible for all errors and ommissions. I have also enjoyed intellectually stimulating discussions with Didi Kwartanada, Elizabeth Chandra, Endy Saputro, and Sutrisno Murtiyoso.

2 Peranakan refers to the Chinese who are born of mixed marriages between the Chinese men and local women and, therefore, cultivate hybrid cultures.

3 The first version was published in 1897 by G. Kolff and Co in Batavia. In 1910 and 1913, there were publications by Kho Tjeng Bie and Goan Hong respectively. Both claimed they published the second versions. The Kho Tjeng Bie's version added the word "nabi" (prophet) 
Applying critical discourse analysis (hereafter CDA), my goal is to highlight that Lie chose the figure of Confucius to promote a type of piety in which personal virtue, self-respect, and high standards of morality should be expressed through political actions, active citizenship and the promotion of good governance. By describing Confucius, his teaching and actions, Lie was intimating that his fellow Chinese Peranakans reconnect with China as an alternative patronage through which they might attain a position better than their subordinate and second-class status under Dutch colonialism. Before analysing the text, I shall provide the background which influenced the production of the HK. It consists of: (1) knowledge formation about China and Confucianism by the West, (2) Dutch racial policies and their effects on the economic and political conditions of the Chinese Peranakans; and (3) the Confucian revival movement in China and Singapore and its connections with that of the Peranakans in the Netherlands East Indies. Thereafter, I shall describe Lie Kim Hok, his authorship, sources, and agency. The last part analyses the subversive ideas encoded in the HK, including cosmopolitanism, active citizenship, and good governance.

\section{GOVERNING RACE AND THE POLITICAL ECONOMY IN THE NeTHERLANDS EAST INDIES} In the 1814 Grondwet (Constitution), the Dutch colonial government defined its colonial subjects in a system of racial stratification. The first category was composed of the Dutch people, the second of the vreemde oosterlingen (oriental foreigners), and the third was the priboemi (natives). This stratification system extended into other policies. For example, there were separate courts for the three groups. The Chinese - who were classified in the second category, with the Arabs - had to apply to a special court and were governed by regulations designed for their group. The natives were meted out at similar treatment. However, the latter were assigned additional courts and rules, hukum adat (customary laws) and hukum Islam (Islamic laws).

In 1816, the colonial government introduced the wijkenstelsel (quarter system) and the passenstelsel (passport system). Tied to urban area development projects, the wijkenstelsel regulated the settlement of colonial subjects on the basis of their race. In many colonial urban settings were therefore to be found a Kampung Arab (the neighbourhood for Arabs), a Kampung Melayu (the ward for Malays and local people), and a Pecinan (Chinese quarter). In the name of rust en orde (law and order), colonial subjects were required to obtain passes if they wanted to travel $5 \mathrm{kms}$ beyond their settlement. Those who were caught travelling without a valid pass, could be fined or jailed. Although the passenstelsel was abolished for the Javanese in 1863 (Van Hoëvell and Bleeker 1863: 236-239), it was still retained the Chinese.

In 1897, under the pretext of the halting the opium trade, the colonial government imposed the strictest supervision on the Chinese's traveling

in its title, which became Hikajatnja Nabi Khonghoetjoe (The life story of the Prophet Confucius). Other than the title, there was no change in its content. The last edition was published in 1921 by Goan Hong. 
activities. In Opium to Java, James Rush (1990) demonstrates that in the midnineteenth century, opium trading, alongside cash-crop plantation, was the backbone of the colonial economy. The government sold the monopoly to sell the opium in the rural areas to the wealthy Chinese. Later, under the pressure exerted by an ethical commission in the mother country, the colonial government was forced to abolish the opium trade. The purpose of the strict passenstelsel policy was to limit the Chinese opium business networks in the rural areas. The most recent regulation had required them to obtain a pass each time they needed to travel away from home for more than four days for almost any reason. A pass was even required for a journey as short as an hour away from home and for any reason, including emergencies or health concerns. Failure to present a valid pass resulted in a fine of 25 guilders or a month's imprisonment with hard labour. The Chinese experienced devastating financial losses since they were unable to travel to rural areas on businesses and were forced to limit their commercial activities to cities (Tio Ie Soei 1958: 9; Williams 1960: 28-30). In 1911, the passenstelsel was abolished, but it was only in 1919, when the wijkenstelsel itself was revoked, that the Chinese were permitted to settle in other parts of a town (Bloembergen 2007: 124).

The abolition of the opium trade was a measure taken to support the newly introduced Ethical Policy which sought to ensure that the native people were better treated. Some Dutch ethicists had advocated positive actions on the behalf of the natives by campaigning against the policy of a liberal economy which they considered an "unjust and un-Christian" practice (Mansvelt et al. 1994: 217; Adam 1995: 71-72). This was followed by a negative campaign against the Chinese, which grew out of the fear of a "yellow peril". Chinese economic power, which had previously been considered one of the main pillars of the colonial economy, was now perceived to pose a dangerous threat to both the natives and the Dutch. Images of the Chinese as spiders and leeches, entrapping the powerless Natives in deep addiction and subsequent poverty by luring them to their opium dens and pawn shops propagated in newspapers and novels alerted the Dutch to what would be considered a growing concern. From their point of view, anything which jeopardized Native's economy posed a threat to their economy (Rush 1990: 198-216). Other negative representations of the Chinese as lawbreakers and felons who ran opium smuggling and illegal trading in rural areas appeared in several official letters from the Dutch officials (Scheltema 1907: 112). By 1896, Lea Williams (1960: 41) notes, most of the newspapers had "begun a crusade against the Chinese". During the campaign against opium, the Chinese not only had to struggle harder to maintain their economic positions, they also found themselves trying to battle against negative images and stereotypes.

\section{Defining Chineseness AND the ALternatives of A SUbJeCtive position}

In modern colonialism, Chatterjee (1993: 14-34) argues that the making of racial differences is the most powerful method of governing the colonized. "The difference could be marked by many signs, and varying with the context, 
one could displace another as the most practicable application of the rule. But of all these signs, race was perhaps the most obvious mark of colonial difference" (Chatterjee 1993: 20). In the case of British West Indies, it was the difference of the British as a White race which gave them power to govern the inferior Other, the Indian. In the Netherlands East Indies, the Dutch had not only established themselves as the superior White race, they had even created categories among the Other: the Eurasians, the Oriental foreigners (Arab and Chinese) and the natives.

Echoing Chatterjee's work, Naoki Sakai (2005) states that modern colonialism produces an asymmetrical power relationship between the colonizer and the colonized. Embedded in this power imbalance, the colonizers enjoy superior positions which allow them to observe, define, and categorize the colonized by the application of various technologies, such as surveys, censuses, and discriminatory policies. Eventually, the accumulated knowledge of the Other is intended to fashion the West itself as "modern" or "advanced". He terms the act of defining "self" in relation to each other "subjective technology". The difference between Sakai and Chatterjee is that the former argues for the importance of the role of social and dialogic dynamics in the making of the West-and-the-Rest discourse. The social categories, including the West and the Other, are putative, unstable, and continuously being (re)defined apace with the changing economic, social and political situations. In other words, Sakai's point of view allows struggles, resistance, and different positionalities between categories, and this view resonates better in the case of Lie Kim Hok and the Chinese Peranakans, as I shall discuss later in the section on Lie's biography. It also suggests that the dynamics and relativities of social categories recognize the gradient of positionality. A western-educated Javanese, for example, might be categorized as a native by the Dutch, but he might still have been considered a Westerner in relation to most uneducated Javanese. As the discussion below shows, the Chinese Peranakans who appropriated western sources to promote Confucianism might have been considered Chinese by the Dutch but, in their relations with other Chinese totoks, ${ }^{4}$ they were considered a western-influenced group.

The principal focus of Sakai's point of view is on the West and the Rest dichotomy. In the case of the Chinese Peranakans in the late-nineteenth century, the dichotomy was subverted. There were, indeed, opportunities to create "self" through China as a different patronage. In her extensive bibliographical work, Claudine Salmon (1981: 21) investigates the Chinese peranakans' writings from the mid-nineteenth century. In the period of 1878 to 1910, she found the first translations from Chinese by eighteen Chinese Peranakan and newcomer writers, of whom one was Lie Kim Hok. Their works can be categorized as translations of novels, religious or moral canons, Confucian classics and revolutionary polemics. These translations of the Chinese literature and

4 Totok indicates the pure blood Chinese who still maintained their Chinese language skills and culture. The term usually refers to traditionalists with a political orientation to mainland China. 
sources demonstrate that, even though many of the Chinese Peranakans were looking to Malay and European sources for inspirations, some of them were interested in the stories of their ancestors. In his analysis of translation works of the Chinese Peranakans in the late nineteenth century, Didi Kwartanada (2011: 124) demonstrates that these Chinese writers were enthusiastic in acquiring European languages and applying the Roman alphabets instead of the older version of Javanese or Arabic scripts. They, however, used the Romanized Malay to reinvigorate their Chinese culture.

Outside the literary field, the efforts to establish a link with China were begun by the Chinese Peranakans in Surabaya. Salmon (2005: 130) demonstrates that the Chinese Peranakans in Surabaya launched the reform by applying the Confucian calendar as early as the 1880s. Another example is provided by the foundation of Chinese schools in Batavia and Surabaya, as J.E. Albrecht (1897: 231-233) reported. These schools were set up by the Chinese communities as the Dutch government did not provide education for their children. These schools were not high achievers academically and were attended by around 15 to 50 students. In 1879, Albrecht reported that there were several Chinese schools which taught their students to read Chinese and used Confucius' Four Classics as basis of their moral teaching. A school in Surabaya hung a piece of red paper bearing the Chinese characters "the holiest teacher Confucius" on one of its walls and placed a table with a vase in which they could put joss sticks as an offering. ${ }^{5}$ The schools also celebrated Chinese holidays. Eventhough Albrecht wrote that the children could barely read and write Chinese characters even after having attended school for several years, his observation does serve to demonstrate that the imagination of being a part of China and Chinese culture was being actively promoted by various Chinese Peranakans, albeit their efforts were local and on a small scale. Unlike most scholars who believe that the Chinese Peranakans were influenced by the Confucian reform movement founded by K'ang Yu-wei in 1895 (for example, Coppel 1981; Suryadinata 2002), these two examples show that they had commenced the campaign some fifteen years before $\mathrm{K}^{\prime} \mathrm{ang}^{\prime} \mathrm{s}$ movement. ${ }^{6}$

The efforts of the Chinese Peranakans to link themselves to China gained momentum. Just at this time of growing hostility towards and increasing restrictions on the Chinese in the Netherlands East Indies, the Chinese government was changing its political attitude towards the Chinese diaspora. In 1895, after the disastrous Sino-Japan war, a young middle-ranking official, $\mathrm{K}^{\prime}$ ang $\mathrm{Yu}$-Wei, proposed a thorough governmental reform and instigated an institutional change in order to save the nation from further defeat. Even while he was doing his best to convince the emperor and his councillors, K'ang was

\footnotetext{
5 There was no evidence, however, that the life story of Confucius had been introduced in these schools except the conversation between Confucius and a small boy, Hang Thok, in several Chinese school textbooks (Chambert-Loir 2015: 68, footnote 1).

$6 \quad$ Kwee Tek Hoaij (1939: 1-7) asserts that K'ang Yu-Wei and his reform movement had indirect influence to the foundation of THHK (Tiong Hoa Hwee Koan) in Batavia.
} 
already envisaging the overseas Chinese as possible supporters of his vision for a "new China" (Wong Young-Tsu 1992: 517).

Inspired by the Meiji Restoration in Japan, K'ang proposed that Chinese culture be purified and Confucianism be made the state religion (guo jiao) and "the soul of the Chinese nation". He deduced that the humiliations experienced by the Chinese people were the fruit of their deficiency in civic virtues (gongde). Consequently they were experiencing moral degeneration and having struggle to survive in the world (Tay Wei Leong 2010: 105). On June 11, 1898, the Emperor Kwang-Hsu finally endorsed the reform proposed by K'ang. However, it lasted only a hundred days because the Dowager Empress, $\mathrm{C} i$ $\mathrm{X} \mathrm{i}$, and her conservative officials seized back power. After escaping the death penalty, K'ang travelled to thirty-one foreign countries, including Singapore and Batavia, to seek support among the overseas Chinese population (Hummel 1935: 343; Kwee Tek Hoay 1969: 25).

In Singapore, Dr Lim Boon Keng, a respectable Edinburgh-trained physician, hosted $\mathrm{K}^{\prime}$ ang. Lim was a defender and promoter of $\mathrm{K}^{\prime}$ ang's reform programme and his ideas about educational reform resonated with $\mathrm{K}^{\prime}$ ang. In 1895, the same year in which $\mathrm{K}^{\prime}$ ang established the Kongjiao Movement, Lim formulated his thoughts in speeches and articles published in the Straits Times, Thien Nan Shin Pao (Tiennan Xinbao), the Straits Chinese Magazine, and Jit Shin Pao (Ri Xin Bao) (Lee Guan Kin 2006: ix), in the hope that they might reach the Chinese in Batavia. Echoing K'ang's concept of combining classical Confucian scholarship with modern western liberal ideas, Lim laid the stress on educational development by hiring foreign teachers, sending students abroad, and adopting a Japanese educational system (Wang Gung Wu 2006: i).

Williams (1960: 54-55) demonstrates that information was indeed flowing from Singapore to Batavia. Singapore had been the window on the world for Batavia and "an intellectual center" for Chinese Peranakans. However, she notes that a year earlier than Lim's Confucian movement in Singapore in 1898, the HK had been published in Batavia. There is no specific evidence to show that Lie Kim Hok had been influenced by Lim Boon Keng's writing. Discussing K'ang Yu-wei's influence, Kwee Tek Hoay (1969: 1) writes that K'ang had indeed visited Batavia in 1903 and had met the Tiong Hoa Hwee Koan (The Chinese Association - hereafter THHK) board of commissioners (bestuur), of which Lie was head of its Religious Commission (Nio Joe Lan 1940: 203, 213). Considering the chronology, the publication of the HK in 1897 is a telling piece of evidence indicating that Lie Kim Hok had already conceived the ideas of embracing Confucianism and western values years before he met these leaders. It goes without saying, however, that both $\mathrm{K}^{\prime}$ ang $\mathrm{Yu}$-wei and Lim Boon Keng did exert an undoubted influence on Chinese nationalism and the Confucian movement in the Netherlands East Indies in the later period of the early 1900s. One important piece of evidence to back up this statement is Lim Boon Keng's endorsement of the publication of the Su shi (Si shu - Four Classics) by Tan Gin Tiong whom he had met personally in Singapore in 1899 (Kwee Tek Hoay 1969: 5). 
It is worth noting here that although K'ang's idea of reform through Confucian teaching had been repudiated by first the last Manchu monarch and later by the newly emergent Republic of China in 1912, his idea of building support among the overseas Chinese remained intact. As early as 1909, the Manchu ruler issued an imperial decree setting out the definition of a Chinese subject on the basis of jus sanguinis or the blood principle. This meant that China could claim every child of a Chinese father or mother as a Chinese subject, regardless of that child's birthplace. The decree created a problem of dual nationality for the Chinese Peranakan in the Netherlands East Indies as the Dutch claimed that they were Dutch subjects on the basis of Holland's acknowledgement of jus soli or the territorial principle in 1910 (Aguilar 2001: 513-514). Quite apart from any legal disputations, dual nationality opened up opportunities for the Chinese peranakan to consider China-oriented nationalism, something which had not been previously envisaged.

\section{A SHORT BIOGRAPHY OF LIE KIM HOK AND HIS AUTHORSHIP}

Lie was born in Bogor to Chinese Peranakan parents in 1853 and spent his childhood in Tjiandjur (Cianjur), a small town in West-Java. His family had presumably been in the Indies for three or more generations. His father - Lie Hian Tjouw - spoke a high Sundanese (bahasa Sunda halus), the most refined version of West Javanese dialect. His mother - Oey Tjiok Nio - was also a Peranakan woman. Lie learned some old Chinese traditions from his father and local traditions from his mother as was widely practiced by the Chinese families across Java at that time (Tio Ie Soei 1958: 14-17). Unsurprisingly, as a productive writer, Lie was interested in adapting Chinese stories into SinoMalay.

When he was ten years old, Lie attended the first missionary school in Tjiandjur, founded by the missionary, Christiaan Albers. Sundanese was then the language of instruction. In 1866 his parents decided to move back to Bogor where he entered a small private Chinese school run by the sinshe Tan Liok Ie, who was subsequently replaced by a series of other sinshes. Although he gained some basic knowledge of Hokkien, Lie could neither read nor could he write Mandarin. In mid-1866, the missionary Sierk Coolsma opened a small private school in Bogor. Lie continued his education under Coolsma's supervision. Lie was an enthusiastic pupil. Coolsma described "de honger van zijn geest was groter dan die van zijn maag" (the hunger of his spirit was greater than that of his stomach) (Tio Ie Soei 1958: 37). After four years, the missionary D.J. van der Linden replaced Coolsma and changed the language of instruction from Sundanese to Malay. This change might have been prompted by the fact that the Chinese Peranakans were more responsive to and interested in learning about Christianity than the Sundanese. Although the latter were actually the main target of Dutch missionary work, very much to their disappointment, West Java was a predominantly Islamic area in which a rejection of and 
hostility towards Christianity were strong. Van der Linden was apparently aware of this problem and decided to use Malay, which "tended to reinforce the Chinese element in the school" (Coppel 1986: 20). Van der Linden also taught Lie Dutch and presumably other European languages such as French, English, and German as well (Tio Ie Soei 1958: 22-23; Salmon 1981: 228-229).

Lie 's relationship with Van der Linden became closer when he was appointed a teaching assistant in the school. His closeness to Van der Linden helped familiarize him with western values and Christianity. Although he did not convert to Christianity, Tio Ie Soei (1958: 37) argues that "dia melebihkan Keristen daripada banjak orang Keristen" (he was more Christian than many other Christians). It is interesting to note that Lie's father sent his son to a Christian school despite the common Peranakan fear that Christianity might pose a threat to a person's Chinese identity. Despite criticism of his decision, Lie's father was open-minded about the influence of western knowledge and considered it to be a complement to the Chinese tradition which imposed both morality and spirituality through education (Tio Ie Soei 1958: 39-40).

His talent for language meant that Lie was familiar with European texts and novels. Twenty of his writings were apparently either translations of or adaptations from French, Dutch, Chinese, and English novels, including Graaf de Monte Christo (The Count of Monte Christo, 1894) and Hikajat Kapitein Flamberge (The life story of Captain Flamberge, 1908). More than half of his translations of Chinese stories are based on French or Dutch adaptations of Chinese novels. Boekoe tjerita pembalasan dendam hati (The story book of revenge), also known as Ong Djin Gi (1907), for example, was not based on a Chinese story although it was given a Hokkien title. In fact, it was actually an adaptation of a novel by an unidentified French writer. Four of his writings, such as Pek Hauw Thouw (1886) were based on Chinese novels. He wrote them in collaboration with two friends, Tan Kie Lam and Tee Pek Thay, who were literate in Chinese (Salmon 1987: 405). Eleven of his writings have been reprinted, but only the $H K$ has been reprinted as many as four times (Salmon 1981: 229-232).

The case of Lie is an unique demonstration of how the boundary between modern values, Malay cultural traditions, and imagined affiliation to China was beginning to blur. Because he translated various western works, he could be considered as "westernized" and too modern by his fellow Chinese Peranakan. However, his works on Chinese literature, his deep interests in Confucianism and his choice of using the Malay language lifts his subjective positionality beyond Sakai's "the West versus the Rest" binary complexity. His subjectivity simultaneously encompassed three categories: acceptance of modern western values, a political and religious orientation towards China, and linguistic roots in Low Malay (Bahasa Melayu Rendah). ${ }^{8}$ During his lifetime, Lie was a prolific writer, producing 28 stories alongside numerous

8 Henri Chambert-Loir (2015: 86-87) argues that the Low Malay or Sino-Malay worked as an identity marker for the Chinese Peranakans and a struggle against the High Malay (Bahasa Melayu Tinggi) or Riau Malay standardized and supported by the Dutch government. 
articles published in such newspapers as Bintang Barat, Pemberita Betawi, Dinihari, Hindia Olanda, Bintang Betawi, Taman Sarie, Hoekoem Hindia, Siang Po, and Perniagaan. For his efforts popularizing Low Malay through his novels and writings, he has earned himself the epithet of "Bapak Melajoe-Tionghoa" (the Father of Sino-Malay) (Salmon 1981: 231; Tio Ie Soei 1958: 86-87).

Revisiting Lie's work, Tio Ie Soei (1958: 90-91) summarizes the criticism of his works. Instead of translating the original version and acknowledging the source, Lie chose to develop his own plot and details. In Ong Djin Gi, he gives the French characters Chinese names, moves the setting to China, and replaces the European calendarical system with that of Confucius. In Kapten Flamberge, he writes a happy ending to replace the tragic conclusion in its original version. In order to understand Lie's way in translating and writing a novel, I suggest contextualizing it in the broader Malay literary tradition of his time, which was different from that of the western tradition. The Malay tradition considered a piece of literary creation to be the property of a community which meant that most Malay works were anonymous (Salleh 1991: 3-23). The oral tradition of transmitting stories had opened up opportunities for storytellers and other authors to modify tales by experimenting with various fragments, styles or plots, and making a new work in itself. Henri Chambert-Loir (1984: 44) calls this process the "evolution" of literature, while Salleh (1991:3) considers this type of authorship a "conglomerate authorship".

The concept of authorship in a written tradition in Malay did not come into being until the seventeenth century when books were introduced into the Malay literary tradition. It was the British missionary W. H. Medhurst who introduced printing technology to Batavia in 1828 (Van der Putten 1997: 717). In over nearly two centuries since then, compositions on paper have gained a greater sophistication, legitimacy, and authority than oral compositions. Despite the differences between the older and the newly emergent type of authorship and authority, there was still a plenty of space for writers and storytellers to modify stories, to claim an authorship, and to transmit these stories (Millie 2004: 2). At the end of the nineteenth century, when western print capitalism had penetrated deeper in the colony, the Malay writers began to claim story ownership, regardless of the fact that the works they wrote were not their original compositions. These writers also claimed "monetary rights" to their modified works (Maier 1997: 59-60) as copy-rights law (Auteurswet) was only imposed in 1912.

The "monetary right" to these writings was initiated by changing readership patterns in the period since the introduction of print capitalism to the Netherlands East-Indies. Besides listening to oral stories, people could also read written stories by borrowing manuscripts from lending libraries, even though this service was not free in the same sense as a modern library. Borrowers would pay the library-owner a small fee in order to access a text. To ensure continuous and loyal readerships, library-owners copied stories from older manuscripts or wrote down oral stories with some modifications and claimed them as their own. It can be said that contemporaneous Malay 
authors, including Lie Kim Hok, enjoyed a flexibly oscillating role of copyist, translator, and author (Chambert-Loir 1984: 44).

In the last years of Lie's life, in 1910 to be exact, the Manchu dynasty claimed the citizenship of the overseas Chinese. Although there is no record of how this policy might have affected his political view, my argument is that Lie consistently maintained his subjective technology, which embraced three categories of identities - being modern, Chinese oriented and Malay rooted. The record shows that in his last years, he translated more Dutch and French novels, such as Boekoe tjerita kawanan pendjahat (The story of a bandit group, 1910) adapted from a French novel, Rocambole (1859) and its four sequels, into the Sino-Malay language (Salmon 1981: 231). Given the fact that he was one of the founders of the THHK in which he actively engaged as the secretary to board and head of the Chinese religious commission, he was harshly criticized by his Chinese friends for enrolling his children in a Dutch school, instead of a Chinese school, even though he supplemented their education with extra lessons in Chinese language and culture (Tio Ie Soei 1958: 92). In 1909, he received a distinguished service medal, the Seventh order of Kung Pai, from the government of China in acknowledgement of his involvement in and support of various Chinese social organizations, including the Tiong Hoa Oen Tong Hwe (The Chinese Sport Association), the Lie Lun Hwe (the debate group), and the Djin Tiu Hi (Chinese charity bazaar). On 2 May 1912, he visited the THHK and two newspaper offices to discuss the cholera epidemic in Batavia and its surrounding areas and talk about how they could help provide medicine for the poor. The care and attention he lavished on his fellow locals unfortunately lasted only a few days before he himself was diagnosed with typhoid and died in 6 May 1912 (Tio Ie Soei 1958: 82-83).

\section{Analysing the Hikajat Khonghoetjoe: Genre, discourse, and style}

This article applies the Critical Discourse Analysis (henceforth CDA) as a method "to investigate critically social inequality as it is expressed, signaled, constituted, legitimized and so on by language use (or in discourse)" (Wodak and Meyer 2002: 2). The CDA argues that a text which is produced within particular time, space, and historical forces can serve as a reflection of social life and hegemonic ideology. By analysing the concepts of the power, history, and ideology behind a text, the CDA can be useful tool to understand the "pressures from above and possibilities of resistance to unequal power relationship that appear as societal conventions" (Wodak and Meyer 2002: 3).

In analysing linguistic practices, including investigating the meaning behind a text, Norman Fairclough (2002: 123) suggests scrutinizing three elements of social practices: text genre, the representation of figure(s) or social actor(s), and social activity within a practice. I shall discuss the genre of the $H K$ in this section, and the representation of Confucius as a social actor and his activity in the later section.

Raised as a Chinese Peranakan, who was expected to be familiar with the Malay oral tradition, it stands to reason that Lie wrote the life-story of 
Confucius in the hikayat genre, one of the genres in Malay writing, which takes a prose form. It has roots in the Arab-Persian story-telling tradition and can contain a heavy overlap between story and history, which would be categorized separately in the western tradition. Therefore, the translation of the word hikayat into English varies widely from "tale", "story", "life-story" to "history" (Riedhorst and Dykstra 1944).

The gray area between story and history or fiction and facts is one of the most problematic issues in reading the hikayat as a "scientific" work. The question is whether or not a hikayat can be regarded as historical writing. The western standard of "scientific history", which began in the early-nineteenth century, considers identification, systematization, and authentication of primary sources as well as objectivity as essential requirements in any the reconstruction of what 'really' occurred and what can be determined as historical fact (Harrison, Jones, and Lambert 2004: 26-37; Florida 1995: 52). Various hikayats, do go some way towards this by including clear and verifiable dates, places, and events. Written by Abdullah bin Abdul Kadir Munsji in the 1840s, the Hikajat Abdullah is one of the exemplary histories of Melaka, and displays a remarkable clarity of dates, events, and places. However, it is not an uncommon occurrence that the characters, places, and times in a hikayat do not appear in any of the known genealogies or histories. For example, the Hikajat Panglima Nikosia (The tale of Commander Nikosia), published in the Sarawak Gazette in 1873 and written at an unknown date (Walker 2005) and the Hikayat Siti Mariah (The story of Siti Mariah) published in Medan Priyayi in 1910 also written at an unknown date (Toer 2003), contain unverifiable characters and times even though the descriptions of places in these stories are realistic.

The blurring of boundaries between story and history, fiction and fact, historical and literary works in the Malay tradition requires a different understanding to that applied to the western standard of "scientific history". Traditional Malay historical writing follows a different practice in which the "truth" does not lie on historical facts but rather in the moral obligation of the author to present the story with God's blessings. Its purpose is to remind the readers that God is the only truth while human beings, including the author, can err. As an oral tradition within a "conglomerate authorship", the hikayat is usually told and retold from older to younger generations, a custom which opens the possibilities for the tellers or writers to modify it into their own style. Therefore, in the introduction to an older hikayat, an author refers to his/her genealogical web, in order to testify his/her starting point and his/ her relationship to "knowledge" (Salleh 1991: 3-7, 9). This can be seen as his acknowledgement of his borrowing to his ancestors and, to some extent, a guarantee of the quality of his work.

The $H K$ consists of an introduction and main text. It has a linear plot that begins with a genealogy of Confucius' ancestors dating back to as far as 2237 BC. The genealogy provides information about Confucius' forbears and illustrating the roots of his exemplary character and philosophical teaching. The story continues with Confucius' birth, childhood, adulthood, his teaching, 
and old age. In choosing the hikajat genre to introduce Confucius to his Malay readers, I argue that Lie Kim Hok derived at least two benefits. Firstly, he could enjoy the advantages of "conglomerate authorship" through which he acquired some degrees of flexibility and agency to modify and appropriate his story. I shall show the ways Lie selected and quoted the original texts in the next section.

Secondly, the hikajat genre allows him to introduce Confucius as a real historical figure. As discussed above, a Malay author can use the hikajat genre to write a tale and/or fiction. Lie had also applied the hikajat to a fictive character in his novel, Hikajat Kapitein Flamberge (1907). which was an adaptation from a French novel written by Paul Sanière, Flamberge (1887) (Salmon 1981: 231). A comparison of the HK and the Hikajat Kapitein Flamberge, however, shows that Lie put more efforts into introducing Confucius as a real historical figure by incorporating his life into the history of the ancient kingdoms in China. It takes him more than four pages to enumerate dates and names of his ancestors. He also emphasizes that the genealogy of Confucius had been verified or is known for sure (sabagimana jang kataoean dengan pasti) ${ }^{9}$ (Lie Kim Hok 1897: 12). In the Hikajat Kapitein Flamberge, on the other hand, he explains neither the origin of his character nor affirms that Flamberge was a real figure. Introducing Confucius as a real historical figure is, in my opinion, one of Lie's main strategies for emphasizing the status of Confucius as an excellent role model and social actor whose teachings are still "appropriate" (patoet) and "obligatory" (wadjib digoenaken) for contemporary people (HK, Lie Kim Hok 1897: 10).

Writing With the West, AGAinst the West: SOURCES, INDIRECT AGENCY, AND THE CITATION POLITICS

In the previous section, I have discussed the agency of Lie Kim Hok as a Malay author in choosing the hikajat genre and utilizing it to introduce Confucius as a great role model for his fellow Chinese. In this section, I would like to highlight another aspect of Lie's agency as an author in choosing and appropriating his sources. In line with the tradition of anonymity and conglomerate authorship commonly practised in Malay writing, it was not uncommon for Malay writers and oral story-tellers to adopt and adapt stories without citing their resource(s). Nevertheless, in the HK Lie chose to identify one of his sources. In the introduction, he mentions J.L. de Lanessan, a Frenchman (saorang Prasman), who, to the best of Lie's knowledge, was superbly familiar with the teaching of Confucius. De Lanessan, who had been a former Governor General of Indo-China, wrote La morale de philosophes Chinois; Extraits de livres classique

9 Since the boundary between real and fiction can be unclear in Malay writing tradition, it was not uncommon an author added a subtitle "ada soenggoeh kedjadian" (really happened in ...) to emphasize the factuality of his story. Lie did it in one of his works "Sair tjerita di tempo tahon 1813 soeda kedjadian di Betawi, terpoengoet dari boekoe Njaie Dasima" (A story tale that had happened in 1813 in Batavia, adopted from the book of Njaie Dasima). 
de la Chine et de l'Annam ${ }^{10}$ (The moral of Chinese philosophers; Excerpts from classical books of China and Annam; hereafter La morale) which was published in 1896, a year earlier than the first publication of the HK.

In the other parts of his introduction, three times Lie cites comments and sayings from a source whom he calls "saorang boediman bangsa Eropa" (an European gentleman), "itoe toewan boediman" (that gentleman), and "soewatoe toewan boediman" (a gentleman) (Lie Kim Hok 1897: 1, 9). The mention of De Lanessan twice and the other European gentleman three times raises several questions about his sources: Was De Lanessan's the only texts Lie adopted? If so, how closely did he borrow the ideas from it? If not, what are the other text(s) he used? Is it possible that he borrowed the work of a Dutch, British, or German writer?

I began my investigation into these questions by juxtaposing the $H K$ and the La Morale. The juxtaposition shows that from the 124 pages of the $\mathrm{La}$ Morale, Lie took only four and a half pages of the introduction and one and a half pages of the moral apotheosis in the last section to incorporate into his introduction. The main texts of both are written using a totally different structure and content. La Morale consists of proverbs originating from the Si shu (Four Classics). It does not cover the biography of Confucius, which means Lie must have referred to other western texts to compose the lifestory of Confucius. As Salmon (1981: 231) indicates the HK is , "(a) study on Confucius based on Western studies, among others on a work by the French Civil Servant, J.L. de Lanessan entitled La morale des philosophes Chinois [...]". Salmon did not, however, mention the HK's other sources.

A long research throughout the older works on Confucianism and Chinese religion(s) collected by the Royal Netherlands Institute of Southeast Asian and Caribbean Studies (KITLV) in Leiden and the National Archive (KB) in The Hague has led me to various works by European sinologists, including the well-known James Legge's The religions of China (1880) and The life and teaching of Confucius; With explanatory notes (1867) and Henri Borel's De Chineesche filosofie; Toegelicht voor niet-sinologen (Chinese philosophy; Explained to nonsinologists) (1896). None, however, is close to the HK.

Further research led me to De heilige boeken der Chinezen, of de vier klassieke boeken van Confucius en Mencius (Khoeng-tseu en Meng-tseu), voorafgegaan door een inleidend levensberigt van Confucius en Mencius, en voorzien van ophelderende aanmerkingen en historische aantekeningen, naar de beste Europesche vertalingen door den bewerker van de Nederduitsche uitgaaf van den Koran (The holy books of the Chinese, or the four classical books of Confucius and Mencius, with an introductory note on the life sketches of Confucius and Mencius, and furnished with explanatory remarks and historical notes to the best (standard) of European translation by the editor of the Dutch-German edition of the Qur'an; hereafter De heilige boeken), which was published by J.J. van Brederode of Haarlem in 1862. Reading this book in conjunction with the $H K$, I found the most striking similarities are between these two. This discovery led me to the 
conclusion that De heilige boeken was Lie's main source for the HK.

As there is no author's name mentioned in the book, another investigation in the KB led me into the name of Salomo Keijzer (1823-1868), the editor of the Dutch-German edition of the Qur'an. Keijzer was a professor at the Royal Academie in Delft, the Netherlands, who had travelled to the Netherlands East Indies and Mekkah (Mecca) in order to research Islamic law and the hajj pilgrimage. The translation of the De heilige boeken was possibly his sideline project since most of his writings and publications are about Islam and the life of the natives in Java. ${ }^{11}$ From his introduction, readers are left with an impression of how deeply Keijzer admired and valued Chinese philosophy. The KB catalogue also includes a note that Keijzer translated the Chinese classics into Dutch from the work of a French writer Jean Pierre Guillaume Pauthier (1801-1873). Since Keijzer does not mention his name in De heilige boeken, it is understandable that Lie could only refer him as "an European gentleman" or "that gentleman" in his introduction.

Examining Lie's decision to use De Lanessan's and Keijzer's as the sources of the $H K$ raises questions about why he chose these two books among all the books to which he had access? What was so special about these books compared to the others? What if these two books were the only books about Confucius Lie could find in the colony?

Regarding to the last question that expresses some doubts about whether people in the Netherlands East Indies had access to the knowledge and books being circulated in Europe, Lisa Kuitert shows that from the mid-nineteenth century, greater numbers of books were being imported to the colonies, including the Netherlands East Indies from Europe. This tallies with the increasing rate of literacy and the subsequent growing readership. In 1883, there were seventeen book-selling companies (boekhandel) throughout Java, whose business was importing books from Europe and circulating them in the colony. ${ }^{12}$ That number grew to 30 in a decade and this is not to mention the numbers of bookshops (boekwinkels), small libraries, or book-renting kiosks. The total weight of books exported from the Netherlands to the Netherlands East Indies was 45,693 kilograms in 1860 and rose to 111,233 kilograms in 1880. If an average book weight is 250 grams, this means in 1880 there were around half a million books circulating in the colony of various themes and formats, including bulletins, magazines, advertisements, textbooks, novels, and popular scientific books (Kuitert 2011: 76-77). Given the fact that Lie could lay hands on a copy of the La Morale, which was published only one year earlier than the $H K$, there must have been other opportunities for him to access the works of

11 See, for example, Kitab Toehpah; Javaansch-Mohammedaanschregt (The Toehpah Book; The Javanese-Islamic Law) (1853), Schetsen uit het leven der inlanders op Java; I. De bedevaart naar Mekka (Sketches from the native' lives of Java; I. The pilgrimage to Mekkah) (1868), Het Mohammedaansche strafrecht naar Arabische, Javaansche en Maleische bronnen (The Islamic criminal law from the Arabic, Javanese and Malay sources) (1857), and Onze tijd in Indië (Our time in Indie) (1860).

12 Several boekhandels might also have business in book printing and publication (Kuitert 2011: 77). One of them was G. Kollf \& Co of Batavia, where the first edition of the HK was published. 
the other European sinologists I mentioned earlier. Therefore, I also have to assume the possibility that Lie might have had different books to use as his sources when he planned to write the HK.

I would like to argue that, in choosing his sources, Lie exercised his agency as an author who wanted to promote Chinese philosophy and culture as a counter to the vilification and humiliation to which his people were being subjecte after the abolition of the opium trade. The reason Lie chose De Lanessan's and Keijzer's works was perhaps because both were more positive about Chinese culture than the works of other sinologists. Both even considered Chinese culture to be equal to European culture, which possibly positions them as the earliest European sinologists to promote cultural relativity and egalitarian attitudes - at least to judge them from their introductory remarks.

In his introduction, De Lanessan (1896:1) mentions that he hopes his book will "set light to western eyes" to Confucianism, which was a little known philosophy in Europe even though it had been enormously influential in China and Annam. He adds the observation that, far from the common judgement that they were uncivilized people, the Chinese and Annamese had developed their own school system and incorporated Confucian teaching into it. This teaching had provided these people with an important moral and philosophical background, instilling in them how to be good members of the family, community and nation. Even though De Lanessan considered Confucianism to work in a way parallel to Christianity in European society, he does distinguish between the two because, rather than focusing on metaphysical concerns, such as soul, divinity and afterlife, Confucianism addresses morality and worldly matters. He concludes by stating his admiration for the longstanding nature of the deep beliefs in and absorption of Confucianism into the daily lives of these people.

In introducing Chinese philosophy, Keijzer also raises the self-criticism of European ethnocentrism in relation to the rest.

In our way of thinking, we despise all things that differ from the accepted ideas in Europe, whereas (Europe is) actually the smallest part of the world and we developed our civilizations based on the civilizations of ancient peoples and other regions. It will sound strange for us, when we use our perspective, that - perhaps since the invention of printing technology, which made publications come to our hands - there are very rare works which are standing higher than the writings of Confucius. In his character whose life sketch is given in the following pages, one discovers the reflection of the noble soul, amiable character, comprehensive mind, broad vision and lofty principles. (De heilige boeken 1862: 1.$)^{13}$

13 All translations from Dutch, French, and Malay are mine unless it is stated otherwise.

The original Dutch text: "Bij onze begrippen, waardoor wij alles minachten wat afwijkt van de aangenomen denkbeelden in Europa, hetwelk toch het kleinste deel der wereld uitmaakt, en welks beschaving op die van vroegere bevolkingen en andere streken is gebouwd, zal het welligt vreemd klinken, dat, volgens onze overtuiging, onder de werken die, sedert de uitvinding der boekdrukkunst, het publiek in handen zijn gekomen, er zich misschien zeer weinige bevinden, welke hooger staan dan de geschriften van CONFUCIUS, waarin men de afspiegeling ontdekt van de edele ziel, het beminnelijk karakter, den veelomvattenden geest, 
The attitudes of De Lanessan and Keijzer contrasted sharply with that of James Legge, the famous Scottish sinologist, whose various of his works have been translated into multiple European languages, including Dutch. In The life and teaching of Confucius, he begins with a criticism of the Chinese people.

"And have you foreigners surnames as well?" This question has often been put to me by Chinese. It marks the ignorance which belongs to the people of all that is external to themselves, and the pride of antiquity which enters largely as an element into their character. If such a pride could in any case be justified, we might allow it to the family of the K'ung, the descendants of Confucius. (Legge 1867: 55. $)^{14}$

Even though Legge did not clarify why and how the $\mathrm{K}^{\prime}$ ung family might have to bear responsibility for such a self-centered attitude, he implies that this pride originated in the establishment of an ancestral genealogical system through which the Confucius' decendants could claim their ancient nobility.

So far the CDA has not been noted for many discussions about choosing resource texts and citing practices as types of author's agency. In the case of the $H K$, I argue that its citation and translation practices reflect a type of author's agency, which is a form of indirect subversion against the West by borrowing the westerners' voices as Lie's opening remark shows.

As the readers may have known the continent of Europe is the smallest among five others, (however) White people who originally lived on this continent or who have origins from this continent, especially in the present time, have been acknowledged as the most cultivated people in the world. Any matter which is unacceptable by the European's way of thinking is despised by people there; but, a surprise comes to the readers' heart, if, according to a European gentleman who is well-acquainted with Chinese literature, it is said now that among all the books published since the art of letter printing had been founded, there has probably been no better book than KHONGHOETJOE's writings from which one can see clearly its author's kind heart, refined behavior, deep thought, full comprehension and clear and sharp memory. (HK, Lie 1897: 1; capital letters are in original. $)^{15}$

de breede zienswijze en de verheven beginselen van den man, wiens levensschets in de hierna volgende bladzijden wordt gegeven".

14 Legge's major works had been translated into several European languages, but there was no Dutch translation for The life and teaching of Confucius (1876). Therefore, I use the original publication which was in English.

15 "Sabagimana jang Pembatja-pembatja tantoe soedah taoe djoega, sedang benoewa Europa ada djadi bagian boemi jang paling ketjil di antara lima sasamanja, bangsa-bangsa koelitpoetih jang sedjati di benoewa itoe, atawa jang berätsal dari sitoe, terlebih poela pada djeman sekarang ini, haroeslah dikataken ada kalihatan paling berboedi di antara bangsa-bangsa isi doenia. Segala perkara jang tida bersatoedjoe dengan pikiran orang Europa, adalah tertjelah oleh bangsa-bangsa di sana; aken tetapi, brangkali djoega rasa heran nanti datang pada hati Pembatja, kaloe dengan menoeroet katanja saorang boediman bangsa Europa jang kenal baik sama kitab-kitab bahasa Tjina, sekarang ini ada dibilang, bahoewa di antara segala kitab jang telah tersiar dari tempo terbitnja ilmoe menjitak soerat, brangkali djoega ampir tida ada satoe karangan jang boleh dikataken ada bagitoe bagoes, seperti karangannja KHONGHOETJOE di mana ada kalihatan njata sekali pengarangnja poenja hati moelja, adat haloes, pikiran dalam, 
Right at the beginning, Lie playfully contrasts the West and the Rest. He acknowledges Europe as a centre of knowledge and authority, accordingly Europeans have the power to define acceptable manners for the rest of the world. To be considered well-mannered or civilized invariably meant to conform to the European standard of values. However, now Lie has an opportunity to invert the world order which had been imposed by European imperialism through the voice of a particular European gentleman who admits in print that there have been no better books than Confucius' writing. This was a political statement because it opposed to the colonial reality in which the Chinese were categorized as colonial subjects under White Supremacy.

Here I would like to emphasize Lie's agency in transforming Keijzer's text by applying CDA analysis. As Keijzers purpose was to introduce Confucius and his teaching as a criticism of feeling of superiority and ethnocentrism among his fellow Europeans, he uses the pronouns "we", "us", and "our" to imply his insider perspective and judgement. In the HK, Lie transforms Keijzer's first person pronouns into "they" (the Europeans) "them" (people there), and "he" ("a European gentleman) to emphasize his outsider or observer perspective. This changing of pronouns was to turn of actor position and agency on its head. By the way he presents his citation, his readers understand that it is "the European gentleman" who is the actor and agent, who offering the criticism, whereas Lie's role is secondary, even invisible or indirect.

In borrowing De Lanessan's text, Lie deploys this strategy even more elaborately. He changes the subjective position and the voice of authority and supplements it with his own words and intentions in such a way that his Chinese Peranakan readers could interpret them as De Lanessan's words or ideas. De Lanessan wrote:

I think it would be useful to place under the eyes of our countrymen a tangible proof of error they make when they talk about China and Annam as semibarbarous countries [...] This philosophy reveals the mindset of the yellow race, in the same way as the catechism and the Gospels uncover the genius people in the places where Catholicism dominates. The doctrine of Confucius and Mencius dominate China and Annam as the doctrine of Jesus to the French people [...] The form in which this doctrine was taught by the Chinese philosophers to their disciples is analogous to that of employed by the founders of the Christian religion. (La morale, De Lanessan 1867: 1, 6, 8. $)^{16}$

pengartian besar dan ingatan terang dan tadjam".

${ }_{16}$ "J'ai pensé aussi qu'il serait utile de placer sous les yeux de nos compatriotes une preuve tangible de l'erreur qu'ils commettent quand ils parlent de la Chine et de l'Annam comme de pays à demi barbares [...] Cette philosophie révèle la tournure d'es prit de la race jaune, au même titre que le catéchisme et les évangiles décèlent le genie des peuples chez lesquels le catholicisme domine. Chinois et Annamites sont aussi imprégnés de la doctrine de Confucius et de Mencius que les Français de celle de Jésus [...] La forme sous laquelle cette doctrine était enseignée, par les philosophes chinois, à leurs disciples, n'est pas sans analogie avec celle qu'employa plus tard le fondateur de la religion chrétienne“. 
In Lie's words, it became:

Mr. de Lanessan, a Frenchman who is well acquainted with the customs and institutions of Annam (Vietnam) and China, wrote a book in which he acknowledges that the customary laws of these two peoples are equal to the customary laws of Europeans who are renowned for being civilized people; therefore if a person obeys the teaching of Confucius and (that of) his pupil, Bengtjoe, he will be listened to and respected not only in Shanghai or other places in China but also in London and Paris. $(H K, \text { Lie 1897: 7-8. })^{17}$

When De Lanessan published La morale, in his introduction he unequivocally states his intention intimating that he wanted not only to introduce Chinese philosophy to his fellow Europeans but also to refute the common judgement that China and Annam were semi-barbarous countries. De Lanessan's personal admiration of Chinese moral philosophy and politics dominates his nuanced introduction to and epilogue of the book, particularly when he sets out his comparative perspective of Chinese philosophy and Christian doctrines. ${ }^{18}$ On the other hand, rather than presenting Chinese philosophy as having an equivalent value to Catholicism - two philosophies which work in parallel ways in geographically separate places - Lie emphasized that the message of Confucianism is universal in both western and eastern worlds. Lie's work not only represents the desire for an equality with Western culture but also an essential imagination for Confucian followers to be a part of the global world. The juxtaposition of "Shanghai or other places in China" to "London and Paris" reinforces the idea that Confucianism makes these metropolitans accessible and creates universally respectful subjects (jang diendahi dan dihormati). Situated in the racially segregated Batavia and in the context of mounting pressures against the Chinese, the way his message was crafted under the aegis of De Lanessan suggests Lie's strategy was to use Confucianism as a currency by which to attain a better subjective position in and beyond the colonial world. This idea should be taken seriously as no one less than a former governor general of French Indo-China himself had admitted the superiority

\footnotetext{
17 “Toewan de Lanessan, saorang Prasman jang kenal baik adat-lembaga bangsa Anam dan Tjina, ada mengarang satoe kitab, di mana ija menjataken, bahoewa peratoeran adat dari doewa bangsa itu ada bertimbang sama atoeran adat dari bangsa Europa jang telah ternama bangsa sopan; maka djika saorang ada menoeroet betoel pada pengadjarannja KHONGHOETJOE dan goeroe ini poenja moerid jang bernama BENGTJOE, boekanlah sadja orang itoe ada diendahi dan dihormati di Sianghai atawa di lain-lain tampat di Tanah Tjina, hanja nanti diendahi dan dihormati djoega di London dan di Parijs".

18 De Lanessan's sympathy to the Chinese philosophy invited critics from his comrades. W.A.P. Martin (1897: 796-798) criticizes de Lanessan's work as non-academic and closer to propaganda to convince his European comrades that the Chinese and Vietnamese were not semi-barbarous. The work contains mistakes on the premises of the superior qualities of human being, heaven, and afterlife due to de Lanessan's lack of language knowledge. These mistakes came from the decision to depend the work on "the somewhat diluted translation of Pauthier" and the wrong judgment in comparing Christianity and Confucianism. Martin make a final comment by saying: "Their (Chinese philosophy) transforming energy is not to be compared with that of the gospel of Christ".
} 
of Confucian moral teachings. A similar pattern recurs when Lie mentioned that various Christian priests, who had come to China two hundred years ago, felt compelled to praise (merasa ada terpaksa aken poedji) the superb teachings of Confucius (HK, Lie Kim Hok 1897: 5).

While De Lanessan clearly appreciates and considers Confucianism to be on the same level as Christianity, he does draw differences between the two.

Both have this in common: they confine themselves almost exclusively to the moral part of philosophy. However, philosophers in China and Annam differ from the philosophers of most other nations in their almost absolute absence of any metaphysical concern. The issues of free will, soul, divinity and the afterlife do not appear to have any place in their meditations. Their kingdom is in this world, their moral teaching addresses how men with their whole existence must progress and, consequently, will find the reward for their virtues, as well as punishment for their misdeeds on this earth. (La Morale, De Lanessan 1867: 7, italics is in its original. $)^{19}$

Lie did not translate this part. He instead wrote his version of Confucianism which encompasses eastern and western values and emphasizes that it works as a form of universal humanism.

[Confucius said] I am working for everybody without discriminating against any of them, because - in my opinion - all human beings can be considered as one family, and I have been assigned to be a teacher of this family [...] My teaching is a teaching for everyone and should be followed by everyone. (HK, Lie 1897: $31,32.)^{20}$

In these examples, Lie's strategy of translating and citing the western texts is more closely resembles an appropriation, which was a common practice in the Malay writing tradition. Applying "conglomerate authorship", he oscillated between one text to another adjusting them to his purpose. In the introduction, Lie demonstrated some degrees of freedom in selecting, omiting, adding, assembling and/or rewriting his own version. In the narrative of Confucius' life-story, he follows the plot and translates the content of Keijzer's

\footnotetext{
19 “Toutes les deux ont cela de commun qu'elles se bornent à peu près exclusivement à la partie morale de la philosophie. Toutefois, les philosophes de la Chine et de l'Annam se distinguent de la plupart de ceux des autres nations par l'absence à peu près absolue de toute préoccupation métaphysique. Les questions du libre arbitre, de l'âme, de la divinité et de la vie future ne paraissent pas tenir la moindre place dans leurs méditations. Leur royaume est de ce monde, leur morale s'adresse à des hommes dont toute l'existence doit s'écouler sur cette terre et qui, par suite, devront y trouver la récompense de leurs vertus, comme le châtiment de leurs mauvaises actions".

20 "Akoe hendak bekerdja aken goena segala orang, dengan tida memilih siapa adanja marika itoe, kerna - toeroet pikirankoe - samoewa orang poen ada teritoeng pada satoe koelawarga sadja, dan akoe ini ada dititahken akan djadi pengajar di dalam koelawarga itoe [...] Pengadjaran jang dibriken olehkoe, jaitoelah soewatoe pengadjaran jang haroes ditrima dan ditoeroet oleh samoewa orang".

Similar sayings occur several times in the introduction and main text. See Lie Kim Hok (1897: $4,24,31,34,97-98,106)$.
} 
text fairly accurately but not imprudently. Lie chooses to modify or omit certain sentences or paragraphs. For example, Keijzer compared the figures of Confucius and Muhammad in ways which paint the former in a good light but are disrespectful and derogatory of the latter (De heilige boeken 1862: i-ii). Lie dropped Muhammad's name off from his writing and did not take an advantage to promote Confucianism as a better teaching than Islam. When this omission is noted, Lie's intention of dealing with the Dutch colonizer and white supremacy emerges more clearly. His purpose was not to create tension and stir up problems with Muslim groups, nor was he out to encourage superior feelings among the Chinese Peranakans towards other colonial subjects.

Applying the strategy of indirect agency, some people might see his referrence as compliance with western supremacy. I would argue that through an indirect manner, Lie was exercising his agency as an author in the best way he could to write both with the West and against the West. The purpose of borrowing can serve several aims. Firstly, as a Chinese Peranakan who had had no contact with China nor appropriate Chinese language skills, Lie could still make his advocacy of Confucianism convincing to his fellow Chinese Peranakan because of his claim that his referees were people knowlegable about Confucianism and Chinese culture. His second aim is connected with the fact that, as a colonial subject, Lie had to comply with censorship and be wary of the penalties imposed by the press and printed matter regulation of (het drukpersreglement) passed by the Dutch colonial government in 1881 (Kuitert 2011: 75). This regulation paved the way for the scrutiny and the censorship and/or banning of both printed materials imported into the colony from Europe and publications within the Netherlands East Indies, which were categorized as too critical of the government. Some cases reveal that the authors and publishers could be liable for a fine ranging from 200 to 5,000 guilders, a year's imprisonment and thereafter be subjected to close monitoring (Kuitert 2011: 78, 82). Therefore, his translation and citation of materials which were critical to western supremacy but had not been censored prior to their entry into the Netherlands East Indies were an important factor in ensuring that his work circulated with little, or even no, investigation. Another important reason for his circumspection was his safety and ensuring protection from the imposition of a government penalty. As he chose to apply an indirect agency, his criticism was covered by "the voices of the European gentlemen".

\section{FROM COLONIAL SUBJECTS TO MODERN CITIZENS}

In this section, I address the representation of Confucius as a social actor. As suggested in CDA, through the representation of Confucius as the main character and a recounting of his social and political activities, Lie Kim Hok exercised his agency as an author to address the social inequality the Chinese Peranakans faced and to introduce them to the concept of modern citizenship. Embedded in his account of Confucius' morality and his flexibility in crossing borders, in my opinion, Lie is proposing that virtue and morality are actually political and through these the Chinese Peranakans can valorize 
their position and raise themselves from subjects to citizens. Good governance has to be fought for and the Chinese Peranakans should participate in gaining it by actively exercising their citizenship. Crossing borders also evokes an essential idea of cosmopolitanism, through which Lie proposes his fellow Chinese Peranakans an alternative subjective technology. The experiences of the Chinese Peranakans under the Dutch colonizer had contained them in the dichotomy of the West versus the Rest. By introducing them to Confucianism, Lie adds China as another patronage through which they could imagine struggles, resistance and, even, subversion against their subordinate position as colonial subjects. Being cosmopolitan allows them to be more flexible and enables them to cross the rigid boundaries, both physically and imaginatively.

\section{A. CRossing borders And Flexible SUbJects}

In Lie's main text, Confucius is described as having been born in Louw $(\mathrm{Lu})^{21}$ and as being a subject of the kingdom of Louw, but he did not reside there permanently. He visited other kingdoms. He spent much of his life teaching and moving from one place to another when he considered his tasks had been accomplished or when he felt his teachings were not being thoroughly accepted or properly applied by the rulers. His first experience of crossing a border was when he visited the kingdom of Ian at the invitation of the lord of Ian who needed Confucius' advice about enforcing legal reforms. His second visit was to the territory of Tje where he offered advice on good governance. This was followed by various visits to different kingdoms. In between his visits, he spent time teaching in his own school in Louw, in which thousands of pupils faithfully studied under his direction.

The story of Confucius leaving his own country, and his travels from one kingdom to another and the fact he did not belong to the community of the countries which his visited might have reminded the Chinese Peranakan readers of their history of migration to the Netherlands East Indies. Nevertheless, there are huge differences between their stories of migration and that of Confucius. As immigrants, the Chinese were accorded neither respect or acceptance from the local government. In contrast to Confucius who enjoyed respect from and gave local rulers advice, the Chinese Peranakans were relegated to the role of second-class subjects and had no political roles even though they contributed significantly to the Dutch colonial economy. The length of their stays also diverged greatly. Confucius visited and lived in various kingdoms for relatively short periods, whereas the Chinese Peranakan had lived in the Netherlands East Indies for generations. They

21 Keijzer used the closest pronunciation of the Chinese names, places and ranks in Dutch. Lie adjusted them into the Hokkien dialect. For example, Keijzer used Yen-Che for the name of Confucius' mother, Lie used the Hokkien version of it, Gan Tien Tjaij, while the standard contemporary pin yin is Yan Zhengzai. For the names of the kingdoms which Confucius visited, Keijzer used for instance Yen and Tsi while Lie used Ian and Tje for these places. Because their stories of Confucius' visits differ from those of other sinologists and the current version, some of the names and places are unidentifiable. I have chosen to maintain the names and places that Lie used and add their current pin yin version whenever available. 
had assimilated into native communities with whom they had lived together relatively smoothly (Lombard and Salmon 1993; Graaf, Pigeaud, and Ricklefs 1984) before the Dutch came and artificially assigned them a separate category from that of the natives. Whereas Confucius enjoyed the freedom to cross borders, under the strict regulations of passenstelsel and wijkenstelsel the Chinese Peranakans were restrained from travelling beyond their living areas in which they resided.

Another situation which might possibly have triggered an even stronger desire to cross borders was the large-scale emigration from China. At the time Lie was sriting the $H K$, the Southeast Asian region was witnessing an influx of migration. As a part of this global migration phenomenon, Southeast Asia received up to 11 million Chinese immigrants, around four million of whom entered the Netherlands East Indies between the 1880s to the 1910s (McKeown 2004: 158). The massive opening of plantations and mines in the Netherlands East Indies attracted large numbers of mainland Chinese who came either as free immigrants or indentured labourers. Another important contributory factor was the lifting of very restrictive border regulations. ${ }^{22}$ Compared with the Chinese newcomers, the Peranakans found themselves in a complicated position as they had been living in the Netherlands East Indies for generations and were rooted in the various local cultures. It was a bitter irony that they were experiencing the position of being neither completely foreign nor completely local and their mobility was restricted by passenstelsel.

The contrast between their lives and that of Confucius, I argue, could have evoke an essential imagination of themselves as "flexible subjects". My concept of "flexible subjects" is borrowed from Aihwa Ong's (1999) Flexible citizenship, in which the idea is used to describe the power of wealthy Chinese businessmen or top managers to negotiate and benefit from cross-border activities in the modern nation-state era. Since the Chinese peranakans and the natives were marginalized and underprivileged under the Dutch colonial administration, the term "subject", in my opinion, is more appropriate than "citizen". By representing Confucius' flexibility in being able to cross borders and his right to self-determination, Lie is proposing to the Chinese Peranakans that this is what they should claim and fight for. Not long after the publication of the HK, Lie and other Chinese Peranakan leaders established the Tiong Hoa Hwee Koan (The Chinese Association) in Batavia in 1900. The THHK was the first non-European civil organization acknowledged by the Dutch government with which it conducted important negotiations; one of them being to put an end to the passenstelsel, which was finally abolished in 1911 (Kwee Tek Hoay 1969: 58-59). ${ }^{23}$

22 As McKeown (2004) argues, the mass migration was a phenomenon prior to modern nation-state formation and before the discourses of nationalism and citizenship influenced the enactment of strict border controls and immigration regulations.

23 The ideas of crossing borders and becoming modern can also be found in Lie's most famous work, Sjair Siti Akbari (The story of Siti Akbari, 1884), which was reprinted three times. Francesco Benitez (2004: 213) argues that Lie introduced the ideas of a modern subjectivity in the persona of the main character. Framed in a complicated love story, Siti Akbari is depicted 
B. GOOD GOVERnANCE AND ACTIVE CITIZENSHIP: CONFUCIAN MORALITY IN POLITICAL SPHERE

Another strong representation of Confucius is his acceptanceby and the respect shown him by different kings and high officials who were eager to profit from his teaching wherever he went. The respect was not given because of his aristocratic lineage, although this might have assisted in opening his access to the elites. Lie and his European sources seemed to agree that Confucius deserved respect because of his exemplary morality, amiable character, broad vision, and superb teaching (HK, Lie Kim Hok 1897: 5). In the HK, the Confucian teaching, I argue, serves several aims in evoking political awareness among the Chinese Peranakans. Firstly, the representation of his superior teaching was a strategy to refute the negative stereotypes of the Chinese which had been reinforced during the anti-opium campaign. Secondly, the teaching of Confucius could be used as a modus for the Chinese Peranakans to attain greater social and political roles. Using the archetypal figure of Confucius, Lie demonstrates that exemplary morality and social and political actions are inseparable. The kings, high officials, and students and the common people respected him highly and valued him and his teaching principally because he excelled in applying his own words and teaching consequently in every position he held; whether he was a citizen, civil servant, child, father, husband or teacher (HK, Lie Kim Hok 1897: 5-7). In his role as a political subject, his morality guided his political decision.

(Confucius said to his disciples,) "It's been a year that I have lived here (Tje country), but the lord and his officials are still in the same situation as they were at the time I arrived, and his country remains as chaotic as it was before". [...] The lord had remained in his bad habits although he was still paying respect to KHONGTJOE [Confucius]. This teacher has not seen any sign that the lord would put his teaching into practice. Therefore, KHONGTJOE planned to leave in an appropriate manner. (HK, Lie Kim Hok 1897: 32-33.)24

This story implies that it is the obligation of those who believe in Confucian teaching to remain consistent in their morality and uncompromising in their attitude to the ruler's fault. In a nutshell, morality is inseparable from one's actions and choices in the political sphere.

In the reform of governance, Confucius' approach was top-down. He

as a woman of self-determination whose adventures takes her to across various boundaries and categories, although in the end she chooses to follow adat (the customary law). Akbari's womanhood symbolizes "a site of instability that makes manifest both the possibilities of social transformation as well as the anxiety over the possibility of social reproduction".

24 "Soedah satahon akoe ada di sini, tapi Baginda dan sekalian ponggawanja masih sadja ada sabagimana adanja di tempo akoe baroe datang di sini, sedang hal karadjaannja masih djoega tinggal koesoet, sabagimana di tempo doeloe' . [...] Baginda radja tetap sadja di dalam kalakoeannja jang koerang baik, dan maskipoen sanantiasa ija ada membri hormat pada KHONGTJOE, tiada djoega goeroe ini dapat lihat pengadjarannja ditoeroet oleh baginda. Sebab bagitoe, KHONGTJOE merasa ingin aken berlaloe dengan sapantasnja".

A similar theme occurs in pp. 42, 62. 
believed that the leader was the key factor for good governance and therefore should have appropriate conduct so as to maintain the law and order in his country. To the lord of Louw, who wanted to introduce good governance into his country, Confucius advised that he improve the welfare of the people by lowering taxes and abolishing corveé (HK, Lie 1897: 65). Once people's welfare had been improved, the lord should enforce law and order, the proper observance of morals and customs.

It also becomes clear that, through the figure of Confucius, Lie wanted to criticize the Dutch colonial policies. For example, Lie wrote about one of Confucius' students, Tjoe Kong, who had been promoted to be mayor of the city of Sin Iang. Confucius gave him the following advice:

"Never give instruction to the people to do VOC-like work (kerjaan koempenian), while they should do farm work, or different sort of work, which is compulsory" (HK, Lie Kim Hok 1897: 83). ${ }^{25}$

The use of the words kerdjaan koempenian, the latter was derived from the Malay spelling of the Dutch word Compagnie, to refer to Vereenigde OostIndische Compagnie (VOC - United East-Indie Company or Dutch East-Indie Company) $)^{26}$ hints at Lie's strong opposition to the cultuurstelsel or mass plantation system implemented by Governor-General Johannes van den Bosch in 1830, which led to a period of impoverishment of Javanese farmers and villagers.

The starting point of good governance, however, is no more or no less than a disciplining of the lord's conduct so that he will be a good role model for his people. Lie illustrated that, whenever a lord implemented Confucius' advice, his country became strong and his people enjoyed better lives (HK, Lie Kim Hok 1897: 66). Max Weber (1951: 153) notes that a top-down approach has been long embedded in the Confucian tradition in China. In ancient times, the kings were responsible for maintaining the good natural and socio-political order. When a kingdom experienced natural disasters, it was the king who was blamed because of the association between the particular disaster and the leader's lack of moral conduct. It was also the king who assumed the responsibility of educating his people and encouraging them to acquiesce in maintaining social harmony and order. Chaos occurred when people lacked education.

Discussing the criteria of a good leader, Lie put forward two qualities: "following the middle way" (memegang sama tengah) and lee (sic!). Lie argues that there was no simple way to translate the latter into Malay. Following the middle way means a leader should neither be too lenient in enforcing law and order nor too impetuous. Instead, a good leader should think matters over carefully and deliberately before making decisions. Another interpretation of

\footnotetext{
25 "Djangan sekali kaoe soeroeh rahajat lakoekan kerdjaan koempenian, sedang ija-orang misti lakoeken kerdjaan tani, atawa lain-lain kerdjaan, jang tra-boleh (sic!) tida dilakoeken olehnja". 26 The word "kumpeni" was commonly used by Javanese - even long after the Indonesian independence - to refer Dutch people or Dutch colonization in general.
} 
following the middle way is to choose the balance in social relationships: one should be neither arrogant (djoemawa) nor submissive (toeroeti sekalian kahendak orang), but should assume a position between these two poles.

Lee (li) means abiding by right thinking, responsibility, order, customs, appropriateness, politeness, and other good qualities. It means controlling one's ego and knowing one's limits. The observance of lee includes doing one's duty in a timely and responsible manner; telling the truth in an appropriate manner; conferring with others in a considerate way, so that the mode of interaction is neither too high nor too low; fulfilling one's responsibility to the leader, fellow men and subordinates; and taking the opportunity to contribute to the development of country and to bring order to its people.

For a ruler, lee is a key to acquiring charisma because lee consists of fairness, benevolence and an orientation toward the people. It follows that a ruler with lee will in turn be acknowledged by his people. Lee creates not only a strong bond between the ruler and the people, it also fosters people's obedience, support, and loyalty. In contrast to Weber's conception of charisma as being a specific gifts which imbued the recipient with supernatural power, Lie suggests that charisma is behaviour-based, and therefore it can be learned and nurtured. Lee is the core of civilization because it is a tool for reflection, good morality and humanity and it is what sets us apart from the animal world. Lee is also the core of religiosity, for observing lee means fulfilling one's responsibility to God and other human beings (HK, Lie Kim Hok 1897: 37-40, 67-71).

Confucius (KHONGTJOE) had an unswerving determination within his own heart. He believed that God (Allah) had given him a task to provide good teaching. Therefore, he did his best to fulfill his duties in small kingdoms, which were the parts of the empire. Although many times he faced difficulties and deprivations during his journes to remote areas, he has never failed to undertake them. He did not want to withdraw himself from his obligation even though there are big difficulties, people hampered him (from his goals), people were jealous and humiliated him, and, even, there are dangers. In short, nothing could undermine his stout heart and strong will. (HK, Lie Kim Hok 1897: 101.) ${ }^{27}$

The figure of Confucius, Lie suggested, was an active proponent of good governance. On various occasions he was appointed an official and once even a minister of justice (soekouw) in the kingdom of Louw (HK, Lie Kim Hok 1897: 59). He was an uncompromising official who set up good and fair rules,

\footnotetext{
27 “KHONGTJOE ada merasa tetap di dalam hati, bahoewa Allah telah membri padanja kahidoepan di doenia ini, dengan menakdirken, jan ija misti mengoewarken pengadjaran itoe. Maka dengan sabisa-bisanja ija lakoeken kamistian itoe di dalam karadjaan-karadjaan ketjil, jang di masa itoe ada djadi bagian-bagian dari karadjaan keizer. Maskipoen seringkali ija dapat kasoesahan dan kamelaratan besar di dalam perdjalanannja ka tampat-tampat djaoeh, tiada loepoet ija bikin djoega perdjalanan-perdjalanan itoe. Ija tiada maoe berenti melakoeken kamistiannja itoe, maskipoen ada sangkoetan-sangkoetan besar, maskipoen ada orang-orang jang menjoesahi, jang menjindiri atawa mehinai padanja, malah maskipoen ada bahaja djoega. Dengen pendek boleh dibilang, tida ada satoe apa bisa hilangken katetapan hatinja dan kahendaknja jang keras".
} 
although they created enemies and roused jealousy. Often his appointment ended abruptly since the rulers were not persistent enough to apply his advice or corrupt officials maneuvered to end his career. Whenever it was requested by kings and officials, he always gave advice even though he was not a part of government.

Confucius is an examplary of an active and responsible "subject" of the Louw kingdom who could exercise his political rights as a "citizen". Etiénne Balibar (1988: 723, 726) argues that citizenship - a concept derived from Greek's politeia - entails two criteria: "It is bound to the existence of a state and therefore to the principle of public sovereignty, and it is bound to the acknowledged exercise of an individual 'capacity' to participate in political decisions". Looking at Balibar's definition of citizenship, the political position of the Chinese in the colonial world becomes problematic because of the overlap of the "foreign" and "subject" categories. They were "foreign" to the extent that the colonial government denied them the recognition of their roots in and bonds with the Netherlands East Indies. As "subjects", they were obliged to obey colonial policies, but denied political participation. Hence, by representating Confucius' ideas about political rights and his relationship with the rulers and high officials, Lie was hoping to awaken an awareness of their political rights and obligations among the Chinese peranakans.

\section{COSMOPOLITANISM AND AN ALTERNATIVE OF POLITICAL LOYALTY}

On various occasions, Confucius left a kingdom because he considered the ruler was not committed enough to introduce good governance. Hence he left in an according manner and went to another kingdom in which the ruler was interested in his teaching. It was because Confucius' teaching was applicable across times and places, he could always find a place to go and to promote his ideas. Therefore I postulate that the teachings of Confucius encourage cosmopolitan ideas and their political implications usher in a greater flexibility to create an alternative political loyalty. In using the term cosmopolitanism, I am referring to the concept of a global political community which ensures the relationship of reciprocal influences between individuals and states regardless of their origins. Derived from the Greek words of kosmo and polities, which means "world" and "citizens" respectively, cosmopolitanism suggests the spirit of universal humanism which transcends regional particularisms of territory, culture, language, or race. In relation to universal humanism, the spirit of cosmopolitanism supports "a right to visit to which all human beings have a claim, to present oneself to society by virtue of the right of common possession of the surface of the earth" and not to be treated hostilely by another upon arrival in other's territory. This is known as ius cosmopoliticum or "cosmopolitan right" (Cheah 1998: 22-23).

In the introduction to the $H K$ and in several parts of the main text, Lie emphasizes that Confucian teaching is universal and necessary to being a part of global world. 
[...] if a person obeys Confucius' teaching and (that of) his pupil's, Bengtjoe, s/ he will be listened to and respected not only in Shanghai or other places in China but also in London and Paris (HK, Lie Kim Hok 1897: 7-8) ${ }^{28}$

The juxtaposition of "Shanghai or other places in China" to "London and Paris" reinforces the idea that Confucianism creates subjects who are universally respected (jang diendahi dan dihormati). By promoting Confucianism as a universal value or currency offering access to both eastern and western worlds, Lie seems to be suggesting cosmopolitan ideas to his Chinese comrades, even though he does not use this particular terminology.

It goes without saying that the representation of Confucius as a great Chinese sage and philosopher, his genealogy and some stories about the ancient Chinese kingdoms which were closely intertwined the history of Chinese civilization also served an important reconnection to China in the same way Benedict Anderson (1983) suggests the formation of an imagined community. Reconnecting with China, I argue, was related to the idea of self-determination and the possible withdrawal of loyalty from the unfair and repressive Dutch colonial government. China served as another option for patronage, one in which they could define their "self" into a new category and, therefore, make it possible for them to create an alternative relationship to the dichotomy to which they were condemned by the Dutch colonizer. The use of Confucianism to reconnect the Chinese Peranakans with China took an even bolder shape when Lie and his fellows founded the THHK. One of the goals they formulated was "to enhance Chinese culture, as compliant as possible with the rules of the prophet Confucius [...]" ( Nio Joe Lan 1940: 7). They established schools in which Chinese Peranakan children could learn both about their Chinese heritage and about modern (western) knowledge all together. One of the fulfillments of the ideas of being flexible and cosmopolitan subjects was achieved when the THHK was able to send 21 students to study in the Kay Lam Hak Tong - a school provided by the Chinese government for the children of overseas Chinese in February 1907, five years before Lie passed away.

\section{CONCLUSION}

As a Malay writer who applied the hikajat genre, I have demonstrated that Lie creatively crafted his own version of Confucius and Confucianism for his fellow Chinese peranakan. Even though the sage lived more than two thousand years ago, Lie contextualizes his teaching within the Dutch colonial situation. In the $H K$, Lie exercises his indirect agency as an author to propose an alternative technology of self as a way to address and subvert the subordinate position of the Chinese Peranakans under the Dutch racial segregation politics and anti-opium campaign.

28 "[...] maka djika saorang ada menoeroet betoel pada pengadjarannja KHONGHOETJOE dan goeroe ini poenja moerid jang bernama BENGTJOE, boekanlah sadja orang itoe ada diendahi dan dihormati di Sianghai atawa di lain-lain tampat di Tanah Tjina, hanja nanti diendahi dan dihormati djoega di London dan di Parijs". 
Embodied in the figure of Confucius, Lie suggests the concept of the virtuous self, which has multiple elements. It is political, ethical, cosmopolitan, and, yet, connected with their Chinese traditions. Morality should inform one's political choices and actions. Being virtuous is also being supportive of and actively negotiating for good governance - an attitude which he and other Chinese Peranakans used for in the foundation of the THHK.

In real life, Lie practised cosmopolitanism. Although he had never physically crossed the borders of the Netherlands East Indies, he did so in his ideas and political and social activities. While he actively promoted Confucianism and Chinese culture, it did not necessarily hinder him from being a proponent of modernity. It was, indeed, in line with the spirit of cosmopolitanism as the cosmopolitan ethics do not mean detachment from one's roots, commitments and affiliations. Instead, it means an ethos or an ability to go beyond borders - imaginatively or physically - without abandoning "particularities of places, characters, historical trajectories, and fates" (Robbins 1998: 1). The facts that Lie actively promoted Confucianism, participated in various Chinese organizations, adapted European and Chinese novels and wrote in the Sino-Malay language demonstrate that he himself was a flexible subject who subverted the dichotomy between the West and the Rest in the Dutch colonial world.

\section{REFERENCES}

Adam, Ahmat. 1995. The vernacular press and the emergence of modern Indonesian consciousness (1855-1913). Ithaca, NY: Southeast Asia Program, Cornell University.

Aguilar Jr, Filomeno. 2001.“Citizenship, inheritance, and the indigenizing of 'Orang Chinese' in Indonesia", Positions; East Asia Cultures Critique 9/3: 501-533. [Retrieved from: http://muse.jhu.edu/journals/pos/summary/ v009/9.3aguilar.html, accessed on 04-01-2012].

Albrecht, J. E. 1879. "Het schoolonderwijs onder de Chineezen", Tijdschrift van het Bataviaasch Genootschap 25: 225-241.

Anderson, Benedict. 1983. Imagined communities; Reflections on the origins and spread of nationalism. London / New York: Verso.

Balibar, Etienne. 1988. "Propositions on citizenship" (translated by Simon James Critchley), Ethics 98: 723-730. [Retrieved from: http://www.jstor. org/stable/2380893, accessed on 29-04-2016].

Benitez, Francisco. 2004. Awit and syair; Alternative subjectivities and multiple modernities in nineteenth century Insular Southeast Asia. PhD thesis, University of Wisconsin-Madison.

Bewerker van de Nederduitsche uitgaaf van den Koran [Keijzer, Salomon]. 1862. De heilige boeken der Chinezen, of de vier klassieke boeken van Confucius en Mencius (Khoeng-tseu en Meng-tseu), voorafgegaan door een inleidend levensberigt van Confucius en Mencius, en voorzien van ophelderende aanmerkingen en historische aantekeningen, naar de beste Europesche vertalingen 
door den bewerker van de Nederduitsche uitgaaf van den Koran. Haarlem: J.J. van Brederode.

Bloembergen, Marieke. 2007. "The dirty work of empire; Modern policing and public order in Surabaya, 1911-1919", Indonesia 83:119-150. [Retrieved from: http://www.jstor.org/ stable/40376415, accessed on 23-05-2015].

Borel, Henri. 1896. De Chineesche filosofie; Toegelicht voor niet-sinologen. Amsterdam: Van Kampen.

Chambert-Loir, Henri. 1984. "Muhammad Bakir; A Batavian scribe and author in the nineteenth century", Review of Indonesian and Malayan affairs 18/2: 44-72.

Chambert-Loir, Henri. 2015. "Confucius crosses the South Seas", Indonesia 99: 67-107. [Retrieved from: http://muse.jhu.edu/journals/ind/summary/ v099/99.chambert-loir.html, accessed on 03-06-2015].

Chatterjee, Partha. 1993. The nation and its fragments; Colonial and post-colonial histories. Princeton, NJ: Princeton University Press.

Cheah, Pheng. 1998. "The cosmopolitical - today", in: Pheng Cheah and Bruce Robbins (eds), Cosmopolitics; Thinking and feeling beyond the nation, pp. 2041. Minnesota/London: University of Minnesota Press.

Coppel, Charles. 1981. "The origins of Confucianism as an organized religion in Java, 1900-1923", Journal of Southeast Asian Studies 12/01: 179-196. [Retrieved from: http://www.jstor.org/stable/20070420, accessed on 22-05-2009].

Coppel, Charles. 1986. "From Christian mission to Confucian religion; The Nederlandsche Zendingsvereeniging and the Chinese of West Java 18701910", in: David P. Chandler and M.C. Ricklefs (eds), Nineteenth and twentieth century Indonesia; Essays in honor of Professor. J. D. Legge, pp. 15-40. Clayton, Vic.: Southeast Asian Studies, Monash University.

Fairclough, Norman. 2002. "Critical discourse analysis as a method in social scientific research", in: Ruth Wodak and Michael Meyer (eds), Methods of critical discourse analysis, pp. 121-138. London: Sage.

Florida, Nancy. 1995. Writing the past, inscribing the future; History as prophesy in colonial Java. Durham, NC: Duke University Press.

Graaf, Hermanus, Theodore G.Th. Pigeaud, and Ricklefs, M. C. 1984. Chinese muslims in Java in the 15th and 16th centuries; The Malay annals of Sĕmarang and Cĕrbon. Clayton, Vic.: Monash University. [Monash papers on Southeast Asia no. 12.]

Harrison, Robert, Aled Jones, and Peter Lambert. 2004. "Methodology; 'scientific' history and the problem of objectivity", in: Peter Lambert and Phillipp Schofield (eds), Making history; An introduction to the history and practices of a discipline, pp. 26-37. London /New York: Routledge.

Hoëvell, W.R. Baron van and P. Bleeker. 1863. "De afschaffing van het passenstelstel", Tijdschrift voor Nederlandsch Indie I/ 2: 236-239.

Hummel, William. 1935. "K' ang Yu-wei, historical critic and social philosopher, 1858-1927", The Pacific Historical Review 4/4: 343-355. [Retrieved from: http:/ /www.jstor.org/stable/3634045, accessed 30-10-2012]. 
Kuitert, Lisa. 2011. "Censuur in Nederlands-Indie in de negentiende eeuw; Kranten, boeken en het drukpersreglement", in: Marita Mathijsen, Boeken onder druk; Censuur en pers-onvrijheid in Nederland sinds de boekdrukkunst, pp. 75-88. Amsterdam: Amsterdam University Press.

Kwartanada, Didi. 2011. "Translations in Romanized Malay and the Revival of Chineseness among the Peranakan in Java", in: Ronit Ricci and Jan van der Putten, Translation in Asia: Theories, practices, histories, pp. 119-135. Manchester: St. Jerome Publishing.

Kwee Tek Hoay. 1969. The origins of the modern Chinese movement in Indonesia. Translated by Lea Williams. Ithaca, NY: Modern Indonesia Project, Southeast Asia Program, Cornell University.

Lanessan, Jean L. de. 1896. La morale de philosophes Chinois: Extraits de livres classique de la Chine et de l'Annam. Paris: Felix Alcan.

Lee Guan Kin. 2006. "Introduction - A Chinese journey; Lim Boon Keng and his thoughts", in: Wen Ching (Dr. Lim Boon Keng), The Chinese crisis from within (revised edition), pp. v-xii. Singapore: Select.

Legge, James. 1867. The life and teaching of Confucius; With explanatory notes. London: Trübner.

Legge, James. 1880. The religions of China; Confucianism and Tâoism described and compared with the Christianity. London: Hodder and Stoughton.

Lie Kim Hok. 1897. Hikajat Khonghoetjoe; Ditjeritaken di dalam bahasa Melajoe. Batavia: G. Kolff and Co.

Lombard, Denys and Claudine Salmon. 1993. "Islam and Chineseness", Indonesia 57: 115-131. [Retrieved from: http://alliance-primo.hosted. exlibrisgroup.com/UW:all:TN_jstor_archive_3410.2307/3351244, accessed on: 22-05-2007].

Maier, Henk. 1997. We are playing relatives; A survey of Malay writing. Leiden: KITLV Press.

Mansvelt, William, P. Creutzberg, P.J. van Dooren, W. Korthals Altes, and P. Boomgaard. 1994. Changing economy in Indonesia; A selection of statistical source material from the early 19th century up to 1940. The Hague: Nijhoff.

Martin, W.A.P. 1897. "[Review of] La Morale des Philosophes Chinois; Extraits des livres classiques de la Chine et de l'Annam, J. L. de Lannesan (1896), Paris: Felix Alcan", The American Journal of Theology 1/3: 796-798. [Retrieved from: http:/ / www.jstor.org/stable/3153256, accessed on 12-05-2010].

McKeown, Adam. 2004. “Global migration, 1846-1940”, Journal of World History 15/2: 155-189. [Retrieved from: http:/ / www.jstor.org/stable/20068611, accessed on 05-01-2011].

Millie, Julian. 2004. Bidasari; Jewel of Malay muslim culture. Leiden: KITLV Press. Munsji, Abdullah bin Abdul Kadir. 1843[1953]. Hikajat Abdullah. Djakarta/ Amsterdam: Djambatan.

Nio Joe Lan. 1940. Riwajat 40 taon dari Tiong Hoa Hwee Koan - Batavia (19001939). Batavia: THHK.

Njio Tjoen Ean. 1900. Taij Hak atau kitab jang pertama dari pada kitab-kitab soetji dari orang-orang Tjina jang di tinggalkan oleh Nabi Khong Hoe Tjoe (Confucius) 
ja itoe Soe Sie Pek Boen atau Ampat kitab-kitab dari pada ilmoe hikmad jang sanonoh, dan dari pada kaparentahan negri di benoe Tjina jang mana bergoena sekali pada orang-orang Tjina akan mengatahoei agamanja. Ambon: Ambonsche Drukkerij.

Ong, Aihwa. 1999. Flexible citizenship; The cultural logics of transnationality. Durham, NC: Duke University Press.

Putten, Jan van der. 1997. "Printing in Riau; Two steps toward modernity", Bijdragen tot de Taal-, Land-en Volkenkunde 153 (4):717-736. [Retrieved from: http:/ / www.kitlv-journals.nl, accessed on 12-05-2010].

Riedhorst, Johanna C and R.R. Dykstra. 1944. Malay-English; English-Malay dictionary. Southwest Pacific: United States Armed Forces (USAF).

Robbins, Bruce. 1998. "Introduction part I; Actually existing cosmopolitanism", in: Pheng Cheah and Bruce Robbins (eds), Cosmopolitics; Thinking and feeling beyond the nation, pp. 1-19. Minnesota/London: University of Minnesota Press.

Rush, James. 1990. Opium to Java; Revenue farming and Chinese enterprise in colonial Indonesia, 1860-1910. Ithaca, NY: Cornell University Press.

Sakai, Naoki. 2005. "The West; A dialogic prescription or proscription?", Social Identities 11/3: 177-195. [Retrieved from http://search.ebscohost. com/login.aspx?direct=true\&db=a9h\&AN=17941884\&site=ehost-live, accessed on 01/04/2010].

Salleh, Muhammad Haji. 1991. Yang empunya cerita; The mind of the Malay author. Kuala Lumpur: Dewan Bahasa dan Pustaka, Kementerian Pendidikan Malaysia.

Salmon, Claudine. 1981. Literature in Malay by the Chinese of Indonesia; A provisional annotated bibliography. Paris: Editions de la Maison des Sciences de l'Homme.

Salmon, Claudine. 1987. Literary migrations; Traditional Chinese fiction in Asia (17-20th century). Beijing: International Culture Publishing Corporation.

Salmon, Claudine. 2005. "Confucianists and revolutionaries in Surabaya (c. 1880-c1906)", in: Tim Lindsey and Helen Pausacker (eds), Chinese Indonesians; Remembering, forgetting, distorting, pp. 130-147. Singapore: ISEAS.

Scheltema, J. F. 1907. The opium trade in the Dutch East Indies I, American Journal of Sociology 13/1: 79-112. [Retrieved from: http:/ / www.jstor.org/ stable/2762537, accessed on 10-05-2016].

Suryadinata, Leo. 2002. Negara dan etnis Tionghoa; Kasus Indonesia. Jakarta: Pustaka LP3ES.

Tay Wei Leong. 2010. “Kang Youwei, the Martin Luther of Confucianism and his vision of Confucian modernity and nation", The University of Tokyo Center for Philosophy Booklet: Secularization, Religion and the State 17: 97-108.

Tio Ie Soei. 1958. Lie Kim Hok: 1853-1912. Bandung: L.D. Good Luck.

Toer, Pramoedya Ananta. 2003. Hikayat Siti Mariah. Jakarta: Lentera Dipantara. Walker, J.H. 2005. "Hikayat Panglima Nikosa and the Sarawak Gazette; Transforming texts in nineteenth century of Sarawak", Modern Asian Studies 39/2: 427-460. 
Wang Gung Wu. 2006. "Foreword", in: Wen Ching (Dr Lim Boon Keng), The Chinese crisis from within, pp. i-iv. Revised edition. Singapore: Select.

Weber, Max. 1951. The religion of China; Confucianism and Taoism. Translated by Hans H. Gerth. Glenco, Ill.: Free Press.

Williams, Lea. 1960. Overseas Chinese nationalism; The genesis of the Pan-Chinese movement in Indonesia, 1900-1916. Glencoe, Ill.: Free Press.

Wodak, Ruth and Michael Meyer (eds). 2001. Methods of critical discourse analysis. London: Sage.

Wong, Young-Tsu, 1992. "Revisionism reconsidered; Kang Youwei and the Reform Movement of 1898", Journal of Asian Studies 51/3: 513-54. [Retrieved from: http:/ / www.jstor.org/ stable/2057948, accessed on 01-12-2008]. 